\title{
ORGANIZATION OF RHEUMATISM RESEARCH AND TREATMENT IN SWEDEN*
}

\section{J. AXEL HÖJER}

As I understand the term, " rheumatism research " includes clinical investigation for further differentiation, and search for the aetiological factor or factors in acute rheumatic fever and chronic arthritis. "When this factor is discovered and established", says an old textbook, "it should be easy to determine its precise relations to the fairly well studied lesions in several organs." Unfortunately, we know too little to say much about it. In Sweden we thought that in present circumstances we could do nothing better than build an institute for research. This institute, which we hope will open early in 1948, is called " The Institute of Gustav V for Research into the Chief Invaliding Diseases, especially Rheumatism and Poliomyelitis".

It must be admitted that some workers in Sweden are of the same opinion regarding this question as the Secretary of the Medical Research Council, Sir Edward Mellanby. In an Harveian Oration, delivered at the Royal College of Physicians of London in 1938, Sir Edward said: "It will thus be seen how it comes about that the Medical Research Council has not usually adopted the practice of making an organized attack on special diseases except when the problem has developed as part of a larger and more general investigation. It has not, for instance, made a mass attack on such important diseases as rheumatism in its many forms and cancer, although, of course, in both instances it supports a good deal of research by different individuals. It considers that it would be relatively unprofitable to spend the large part of its total resources necessary for the adequate study of these diseases at the expense of other work. Extensive ad hoc research on a disease like rheumatism, however important as a practical problem, is apt to be unprofitable until the master key of its aetiology or some other essential fact has been disclosed. This master key is just as likely to be discovered by the use of the experimental method over a wide field as by the direct study of a particular disease where the experimental method is hardly available at present."

I hope that Sir Edward, my friend since the congress of physiology in Stockholm in 1925, does not mind me arguing a little in the opposite direction, as indeed he does himself on the following pages of his oration. Sir Edward was working at that time on rickets, I myself on scurvy, and there were

* Summary of a lecture given before the Empire Rheumatism Council on October 26, 1946. many threads connecting these two deficiency diseases with the problem of vitamins. Similarly, from rheumatism as a clinical disease there are fine rootlets leading down to the origin of the evil. Laboratory research devises new methods which are necessary if such work is to be pursued to its conclusions, but these methods must be applied to the clinically diseased patient. By following the small but important and often long overlooked clinical features, the research worker may get inspiration.

\section{Research}

Fig. 1 shows the front view of the Research Institute at the Caroline Hospital inStockholm. The Institute is situated between the rheumatism wards of the Caroline Hospital and a park. On the park side is an animal house. The Institute has three floors, one bacteriological, one biochemical, and one physiological, with rooms for twenty-two scientific workers. We aim to provide good modern experimental facilities. Figs. 2 and 3 show the first and third floors. You might say we are starting at the wrong end, no institute being useful in itself if competent research workers are not there. I am glad to say that there are many young scientists already waiting for laboratory facilities so that they can begin work under Professors Nanna Svartz and Hilding Berglund. This year we have founded a Scientific Association as a section of the Swedish Medical Association, to bring together rheumatologists from different quarters and to unify laboratory and clinical research. Further, the Swedish Medical Research Council, a later copy of the British M.R.C., the honoured mother of Research Councils all over the world, has elected a special sub-committee to institute further research into rheumatism and to arrange for co-ordination. Members of this committee are, besides Professors Svartz and Berglund, Prof. Odin of Gothenburg, and Assistant Prof. Jonsson of Stockholm, the latter being first assistant to Prof. Kahlmeter. For virus research we have the institute of Svedberg and Tiselius in Uppsala, and we propose to build another at Stockholm for Dr. Gard, in connexion with the State Bacteriological Laboratory.

In spite of the wonderful scientific results of the war, which extended to medical research as well as to other fields, I am not among the administrators who think it possible to claim final results from science in fixed terms. It may be more difficult to 


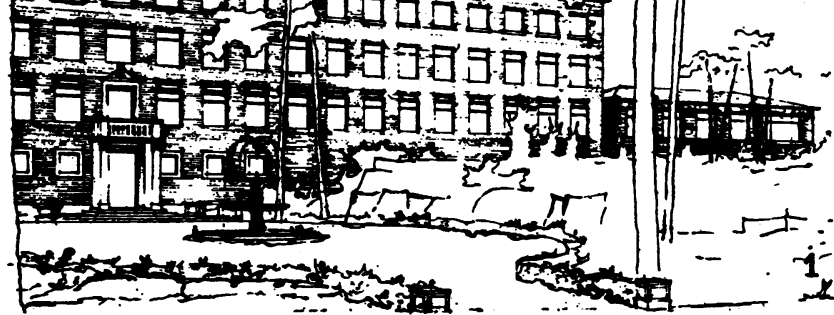

Fig. 1.-Front view of the Research Ins at the Caroline Hospital.

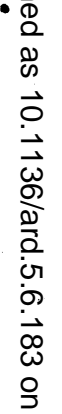

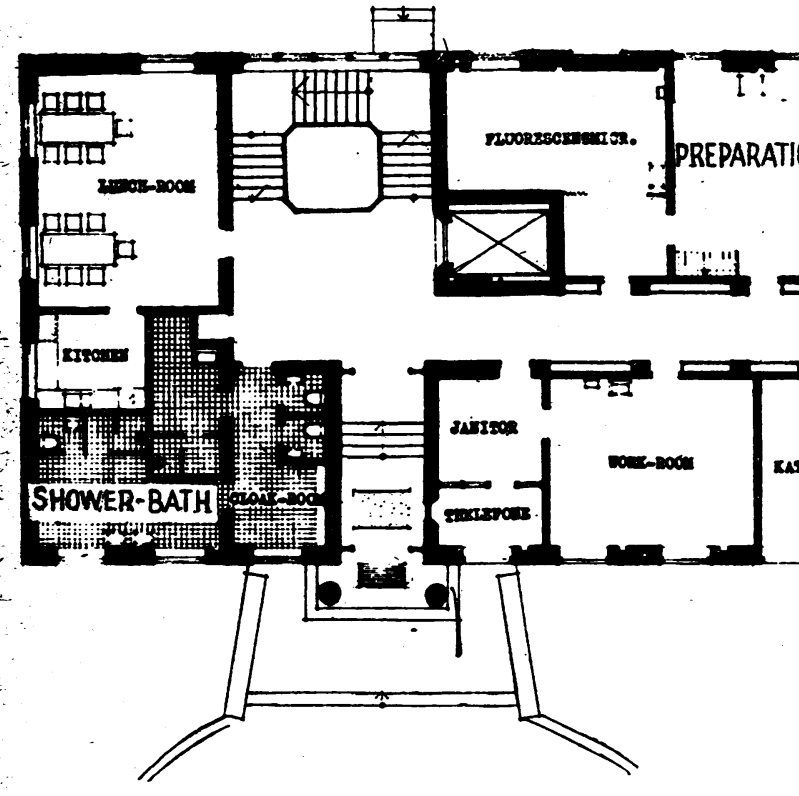

Fig. 2.-The Research Institute at the Caroline Hospital, ground floor.

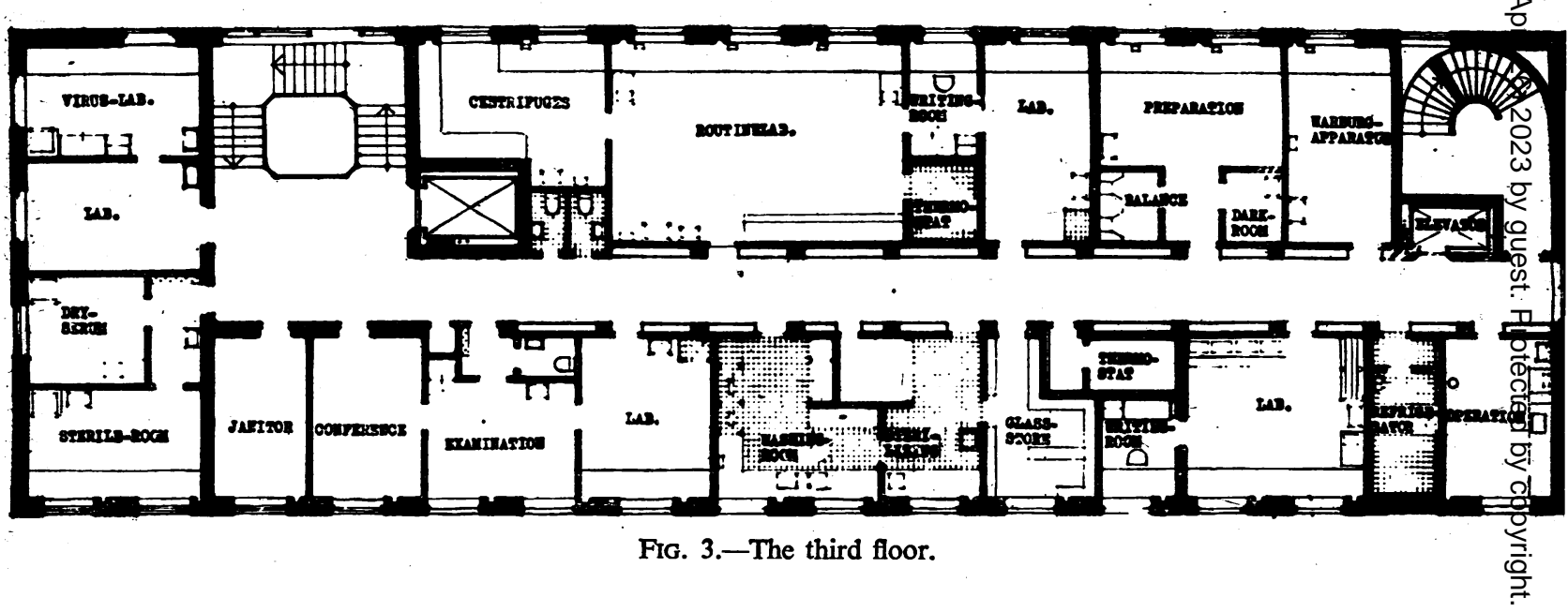


discover the rheumatic virus or other factors connected with rheumatism than it is to invent the atom bomb. Our means in Sweden are modest; they will be increased if, as I hope, English scientists come and take part in the team work of our institutes. The most important fact is that this work shall be co-ordinated with other work on problems of rheumatism which is going on all over the world.

May I explain in a few words the name of the Institute of King Gustav V, because there is a little cultural history connected with it. The people collected 5 million "kronor," $£ 300,000$, in celebration of the eightieth birthday of the King. The same had been done to celebrate his sixtieth and seventieth birthdays. The first jubilee fund gave us the first tuberculosis sanatorium, the second the radiological centre, the Radium Home in Stockholm to fight cancer. Then came the turn of rheumatism. Our King is eighty-eight now, but I am not sure we shall get any more medical centres in this way. The liaison between science and the State is on the way to being more officially acknowledged in Sweden. The money for science is, I think, coming in more regular ways. We have the word of our new Premier, Tage Erlander, that we shall have State money for the yearly budget of the Institutes. In fact, having until recently counted expenditure for science in thousands of "kronor", the Swedish State is just beginning to count in millions.

\section{Treatment}

At the beginning of this century we started in Sweden to discuss the arranging of special rheumatism wards. The names of Dr. Hedenius and Dr. Kahlmeter are to be remembered in this connexion. Between 1920 and 1930 we built between 800 and 900 beds in nine different institutions. The first three of these institutions (Nynäs, Figs. 4, 5; Åre, Figs. 6, 7†; Tranas) were placed in isolated regions far from the centres. At this time such placement was also the rule for tuberculosis institutions and for psychiatric and epidemic hospitals. Even small institutions-for the chronic sick, epidemic diseases, tuberculosis, and so on-were distributed all over the districts, so that the patients should not be too far from their homes. Soon there came a trend toward centralization, and now most of the more remote hospitals are everywhere being brought to the central county hospital, in the shape of psychiatric wards, infectious disease wards, tuberculosis wards, and rheumatism wards. No isolated rheumatism institutions have been built in Sweden since 1925. Instead, since 1925, six hospitals have been built as parts of the departments of internal medicine (Norrköping, Fig. 8†; the others are similar). The chief physician of the general hospital medical wards also controls these rheumatism wards of between 50 and 60 beds. Lund is the only place where there is a special assistant chief for the rheumatism wards (Assistant Prof. Edström).

The therapy in these wards has varied with the chiefs, one preferring gold, another the sulpha drugs,

+ See p. 197. and so on. Sometimes, I am afraid, treatment has been rather routine, every second day physical therapy, the other, rest-just as the rheumatic patients are treated in summer sanatoria. According to Prof. Kahlmeter, the results are excellent, a majority of the patients returning to work or at least having their invalid pensions postponed. I am not convinced, however, that administrative figures give a complete picture of the real medical results. The invalid pension may be postponed, but how about the rheumatism? Nevertheless, I am sure that these hospitals have done a very good work, especially for the chronic forms of arthritis. They are, in fact, necessary.

\section{Planning}

Since 1930 we have not ceased planning and replanning through Royal committees. The first plan of 1934 comprised 9 new special wards with $656^{\circ}$ beds. This plan was not realized. The next committee began to function in 1937, and proposed, in 1941, 21 new wards with nearly 1,300 beds. This plan was not realized either, the counties asking for more State money and the internists for more beds for acute cases. Then the war came bringing some 200,000 refugees. For all cases we built quite a lot of emergency wards, but their standard did not allow them to be incorporated in our regular hospital system. We continued planning, and the plan of 1945 proposed 2,000 new beds for rheumatic patients. This proposition was based on reports from Swedish practitioners concerning all rheumatic cases observed by them in 1943 . I should like to give you some figures from this review. The committee consisted of Prof. Nanna Svartz, Caroline Institute, Assistant Prof. Edström, Lund, one surgeon, Dr. Petterson, from Uppsala, two politicians, and, as Chairman, myself. Nearly 1,400 physicians reported. This is $76 \%$ of all who ought to have done so. Cases reported numbered 66,000 , representing 61,000 patients, half of them men, and half women. The statistician thinks that this represents three-fifths to three-quarters of all rheumatic patients seeing a physician in 1943 . The committee believes that $1 \frac{1}{2} \%$ of the people of Sweden visited a physician in 1943 for rheumatic diseases, and that for the same cause $\frac{1}{2} \%$ were in need of hospital care this year. The number of patients treated in hospitals has been checked by a special report from all hospitals.

\section{Distribution of Cases}

The patients were reported in four groups. Group I consists of cases of acute arthritis, Group II of chronic arthritis. Group III is made up of patients with arthrosis, with degenerative changes; and Group IV comprises all other cases which are generally classified as rheumatism, fibrositis, sciatic neuritis, spinal defects, all sorts of inflammatory processes in muscles, and so on. Fig. 9 shows the age distribution of patients reported to be in need of hospital care, a total of 28,000 , or $46 \%$ of all rheumatic patients. The median age is the age of a 


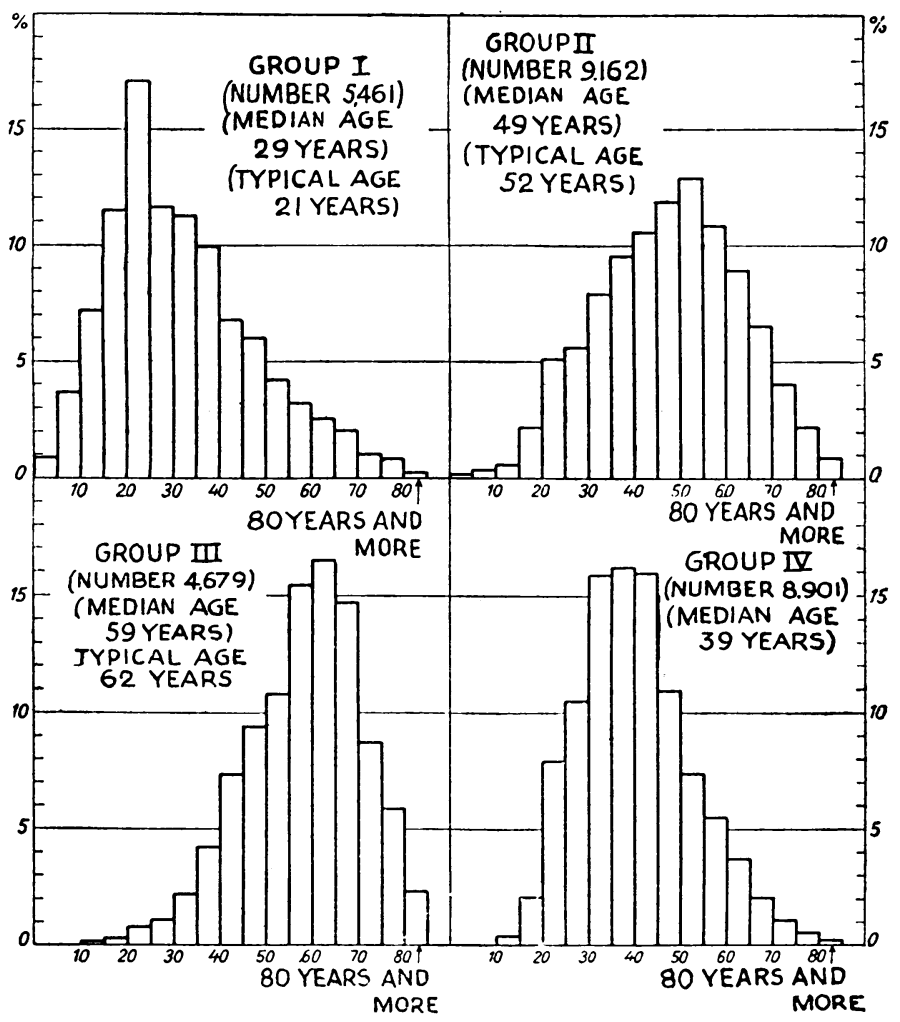

FIG. 9.-Age distribution of patients reported to be in need of hospital care, a total of 28,000 , or $46 \%$ of all rheumatic patients.

patient who has as many younger patients on the one side as older patients on the other. The typical age is the biggest year group. A very low proportion, 5,461 , or $68 \%$ of all patients with acute arthritis, are reported as in need of hospital care. The median age is 29 , the typical age 21. The typical and median age for chronic arthritis patients, of whom $57 \%$ are reported in need of hospital care, is about 50; for arthrosis, of whom $42 \%$ are reported as in need of hospital care, about 60 years. For group IV, which contains all "rheumatic" diseases other than groups I to III, $34 \%$ are reported in need of hospital care, with a median and typical age of about 40.

Fig. 10 shows the cases grouped according to age, in five-year groupings per thousand of the population. The same age distribution can be observed: acute arthritis with its peak in the twentieth year; chronic arthritis with the peak much later, after 50 for women and after 60 for men; arthrosis with its maximum after 60 or 70 years. In fact, the figures increase with age, but the oldest age-groups are not reported. Fig. 10 gives the age-incidence of patients treated in hospitals. The age-incidence for the onset of the disease is given by Edström after local investigations. The figures are very alike, which would mean that the early stages of rheumatic diseases dominate in the hospitals.

\section{Hospital Accommodation}

Fig. 11 shows in the white columns the number of cases in need of hospital care who really got such care. About $15 \%$ of the acute and chronic cases and of the arthrosis cases were entered for admission to hospital but could not be found beds. About an additional $10 \%$ of the acute cases, and nearly $20 \%$ of the chronic cases in need of hospital care were not sent to hospital at all. The cause was very often that the doctor knew there was no chance. Fig. 12 shows that, out of the acute cases cared for in hospitals, $90 \%$ were found beds in general hospitals, whereas less than $10 \%$ werecared for in the special rheumatism wards of the Pension Board. Even the majority

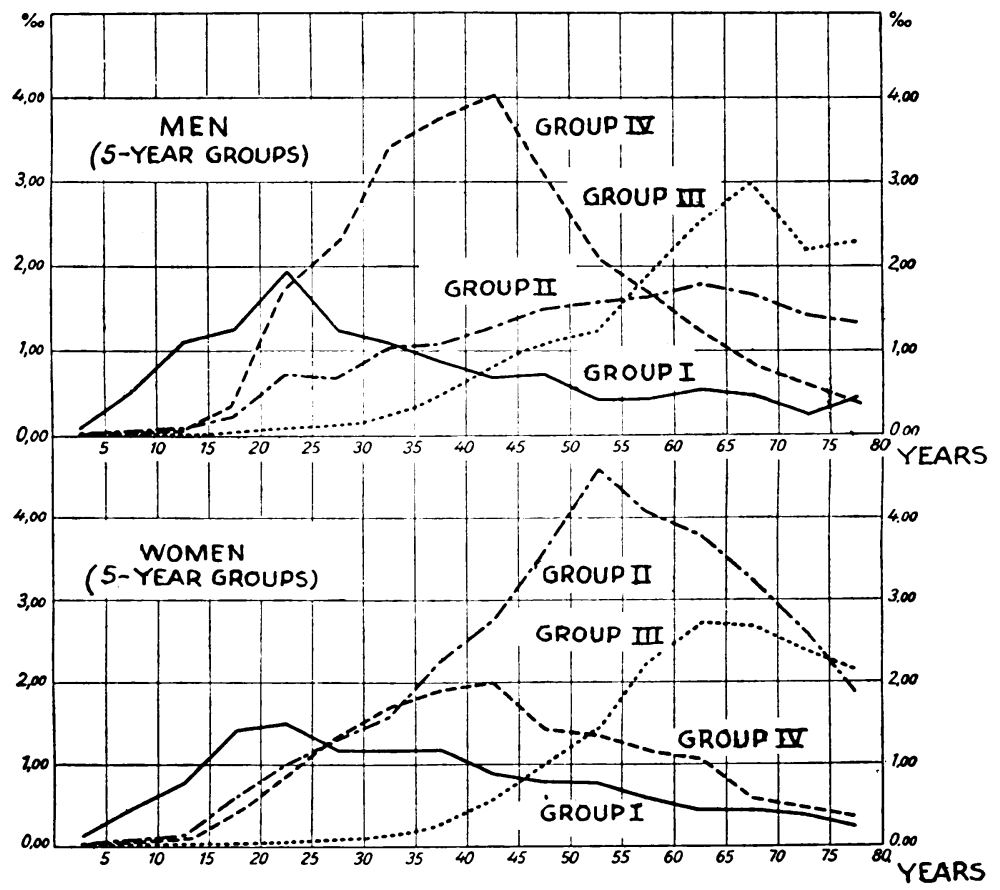

Fig. 10.- Rheumatic patients in different groups, reported to be in need of hospital care during 1943, per thousand of the estimated population in different ages. 
프는 CARED FOR IN HOSPITALS NOT CARED FOR IN HOSPITALS

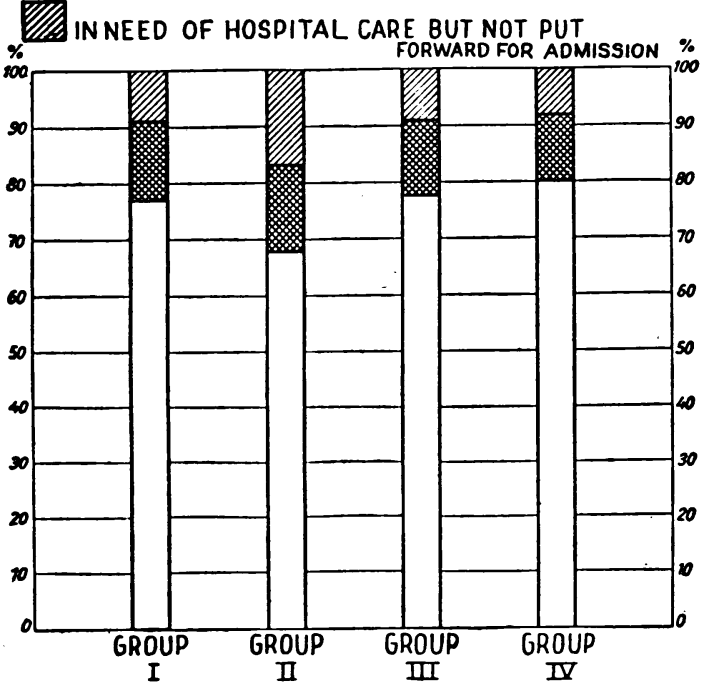

FIG. 11:-Percentage of reported rheumatic patients in need of hospital care, 1943.
GENERAL HOSPITALS OR COTTAGE HOSPITALS ONLY Ua PENSION bOARD'S RHEUMATIC hOSPITALS ONLY ORTHOPAEDIC WARDS ONLY WIW GENERAL (OR COTTAGE) HOSPITALS AND OTHERS

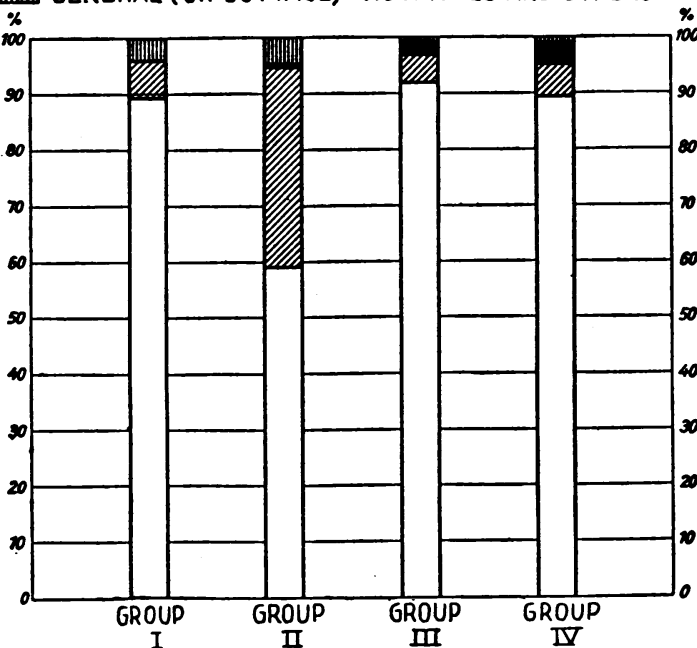

Fig. 12.-Percentage of rheumatic patients cared for in different kinds of hospitals during 1943.

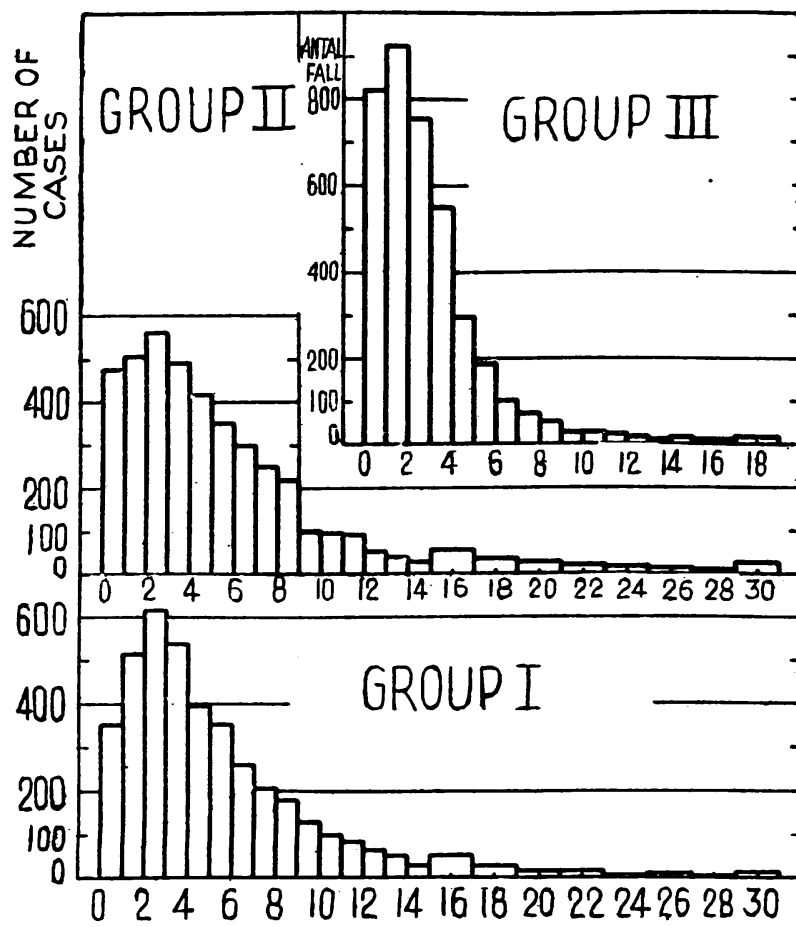

NUMBER OF ATTENDANCE WEEKS

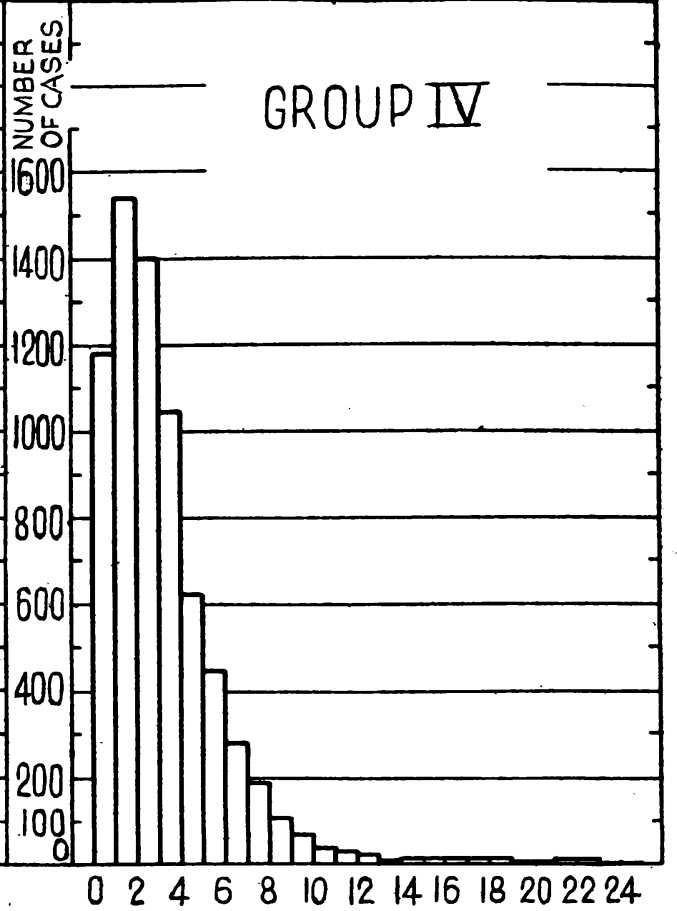

NUMBER OF ATTENDANCE WEEKS

FIG. 13.-Rheumatic patients in hospitals, cottage hospitals, and orthopaedic hospitals (except the Pension Board's hospital wards) discharged during 1943, showing length of stay in weeks. Group I: Number of attendance days, 141, 518; number of cases, 4,047; attendance days, average 35, median 29, typical 19. Group II: Number of attendance days, 148,171; number of cases, 4,152; attendance days, average 36, median 29, typical 19. Group III: Number of attendance days, 81,692; number of cases, 3,872; attendance days, average 21, median 17, typical 12. Group IV: Number of attendance days, 153,520; number of cases, 7,039; attendance days, average 22, median 19, typical 12. 


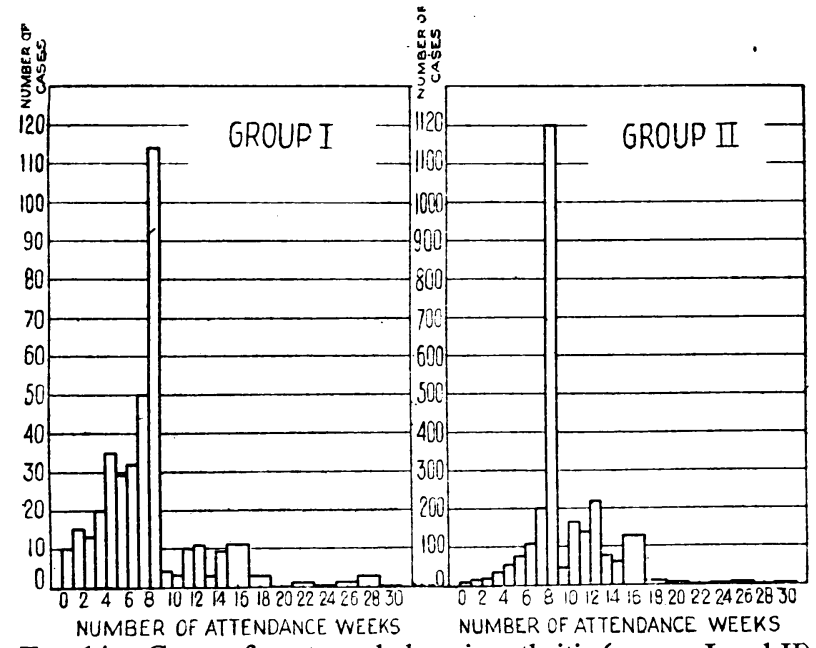

FIG. 14.- Cases of acute and chronic arthritis (groups I and II) in the Pension Board's hospital wards and rheumatism hospitals, discharged during 1943, showing length of stay in weeks. Group I: Number of attendance days, 25,278; number of cases, 411 ; attendance days, average 62 , median 57, typical 59. Group II: Number of attendance days, 172,577 ; number of cases, 2,580; attendance days, average 67 , median 62 , typical 59 .

of the chronic cases, some $60 \%$, were cared for in general hospitals, $35 \%$ in special institutions.

Fig. 13 gives the duration of hospital care. For acute cases the typical stay was 19 days only, the median 29. For chronic cases in general hospitals the figures are the same, 19 and 29 days. For groups III and IV, the median stay is 17 and 19 days, the typical stay 12 days. This period is also very short. Fig. 14 shows that in the wards of the Pension Board the majority of acute and chronic cases have a stay of 2 months, some of them 3 and 4 months. After numerous discussions we have come to believe that the average stay for acute cases should not be less than 60 days, and for chronic cases not less than 90 days. For arthrosis and for the mixed group we think 40 days a reasonable stay. If you increase these periods by weeks, the number of beds needed goes up by hundreds and thousands. For a stay of 1 month longer for cases of acute and chronic arthritis, 3 months in all for acute, and 4 months for chronic cases, you need approximately a thousand more beds.

Table 1 shows the number of civil rheumatic cases in different types of hospitals from 1936 to 1941. The number of patients totalled between 25,000 and 27,000 per annum. Table 2 shows the number of hospital beds which during the whole year 1943 were occupied by rheumatic patients. The total number of beds available for rheumatic patients this year was 2,100, of which 650 beds were in the special wards of the Pension Board and 1,500 in general hospitals, not counting the small homes for chronic sick, into which a number of chronic rheumatic patients find their way. The total number of patients with arthritis (I and II) was only a little greater than the total with arthrosis and miscellaneous complaints (III and IV), but as they stayed longer they occupied a double number of beds.
Table 3 shows the total number of beds required, the number existing, and the deficit. We can see that the beds for acute cases must be doubled and so must the beds for chronic cases. The deficit for chronic cases is three times as great as for acute cases. The beds for acute cases will be provided by dividing up small general hospitals with a surgeon as chief, and adding internal wards with a physician as chief, reserving some of the new beds for rheumatic cases. I think this will be done in the next few years. Even many chronic cases will be taken care of at the general hospitals, but beds for such cases will also be provided in special wards. As a beginning the last parliament allotted money for some 300 beds in special wards, this being two thirds of the planned number. Means for providing more beds will be decided upon when a committee on orthopaedic care in county hospitals has finished its work. In every hospital where there are

TABLE 1

NUMBER OF CIVIL RHEUMATIC CASES IN DIFFERENT KINDS OF HOSPITALS DURING THE YEARS 1936-1941

\begin{tabular}{|c|c|c|c|c|c|c|c|c|c|}
\hline & \multirow{2}{*}{\multicolumn{2}{|c|}{ Groups }} & & \multicolumn{6}{|c|}{$\begin{array}{l}\text { Number of civil rheumatic cases admitted } \\
\text { to all hospitals }\end{array}$} \\
\hline & & & & 1936 & 1937 & 1938 & 1939 & 1940 & 1941 \\
\hline $\begin{array}{l}\text { I } \\
\text { III } \\
\text { IIV }\end{array}$ & $\begin{array}{l}\cdots \\
\cdots \\
\cdots\end{array}$ & $\begin{array}{l}\cdots \\
\cdots \\
\cdots\end{array}$ & $\begin{array}{c}\ldots \\
\cdots \\
\cdots \\
\cdots\end{array}$ & $\begin{array}{l}4,718 \\
8,490 \\
6,084 \\
5,727\end{array}$ & $\begin{array}{l}5,099 \\
8,692 \\
6,615 \\
5,498\end{array}$ & $\begin{array}{l}5,430 \\
8,920 \\
7,163 \\
6,359\end{array}$ & $\begin{array}{l}5,346 \\
8,756 \\
6,564 \\
6,559\end{array}$ & $\begin{array}{l}5,348 \\
8,762 \\
6,016 \\
6,532\end{array}$ & $\begin{array}{l}4,911 \\
9,257 \\
6,726 \\
6,372\end{array}$ \\
\hline & & & & 25,019 & 25,904 & 27,872 & 27,225 & 26,658 & 27,266 \\
\hline
\end{tabular}

TABLE 2

NUMBER OF BEDS OCCUPIED BY RHEUMATIC PATIENTS DURING THE YEAR 1943

\begin{tabular}{|c|c|c|c|c|c|}
\hline \multirow{2}{*}{ Groups } & \multicolumn{2}{|c|}{$\begin{array}{l}\text { Number of days for } \\
\text { the rheumatic } \\
\text { patients who, during } \\
1943 \text {, were discharged } \\
\text { from: }\end{array}$} & \multicolumn{3}{|c|}{$\begin{array}{l}\text { Number of beds occupied by } \\
\text { rheumatic patients during } \\
1943 \text { (number of days } \\
\text { divided by } 360 \text { ) }\end{array}$} \\
\hline & $\begin{array}{l}\text { The Pen- } \\
\text { sion } \\
\text { Board's } \\
\text { establish- } \\
\text { ments }\end{array}$ & $\begin{array}{l}\text { Other } \\
\text { kinds of } \\
\text { hospitals }\end{array}$ & $\begin{array}{l}\text { The Pen- } \\
\text { sion } \\
\text { Board's } \\
\text { establish- } \\
\text { ments }\end{array}$ & $\begin{array}{l}\text { Other } \\
\text { kinds of } \\
\text { hospitals }\end{array}$ & Total \\
\hline $\begin{array}{l}\text { II } \\
\text { III } \\
\text { IV }\end{array}$ & $\begin{array}{r}25,278 \\
172,577 \\
11,086 \\
25,065\end{array}$ & $\begin{array}{r}141,518 \\
148,135 \\
81,692 \\
153,520\end{array}$ & $\begin{array}{r}70 \\
479 \\
31 \\
70\end{array}$ & $\begin{array}{l}393 \\
412 \\
227 \\
426\end{array}$ & $\begin{array}{l}463 \\
891 \\
258 \\
496\end{array}$ \\
\hline Total & 234,006 & 524,865 & 650 & 1,458 & 2,108 \\
\hline
\end{tabular}

TABLE 3

NUMBER OF BEDS NEEDED

\begin{tabular}{|c|c|c|c|c|c|c|c|}
\hline \multirow[b]{2}{*}{$\begin{array}{c}\text { Group } \\
\text {," } \\
\text { ", } \\
\text {," }\end{array}$} & \multirow[b]{2}{*}{$\begin{array}{l}\text { I (acute arthritis } \\
\text { II (chronic ," } \\
\text { I + II } \\
\text { III (arthrosis) } \\
\text { IV (other cases) } \\
\text { III + IV .. }\end{array}$} & \multicolumn{2}{|c|}{$\begin{array}{l}\text { Total } \\
\text { number } \\
\text { required }\end{array}$} & \multicolumn{2}{|c|}{$\begin{array}{c}\text { Existing } \\
\text { beds }\end{array}$} & \multicolumn{2}{|c|}{$\begin{array}{c}\text { Existing } \\
\text { beds sub- } \\
\text { tracted from } \\
\text { total } \\
\text { required } \\
=\text { new beds } \\
\text { required }\end{array}$} \\
\hline & & $\begin{array}{r}949 \\
2,415 \\
570 \\
1,031\end{array}$ & $\begin{array}{l}3,364 \\
1,601\end{array}$ & $\begin{array}{l}463 \\
891 \\
258 \\
496\end{array}$ & $\begin{array}{r}1,354 \\
754\end{array}$ & $\begin{array}{r}486 \\
1,524 \\
312 \\
535\end{array}$ & $\begin{array}{r}2,010 \\
847\end{array}$ \\
\hline Total & $\begin{array}{llll}\ldots & \ldots & \ldots & \ldots\end{array}$ & & 4,965 & & 2,108 & & 2,857 \\
\hline
\end{tabular}



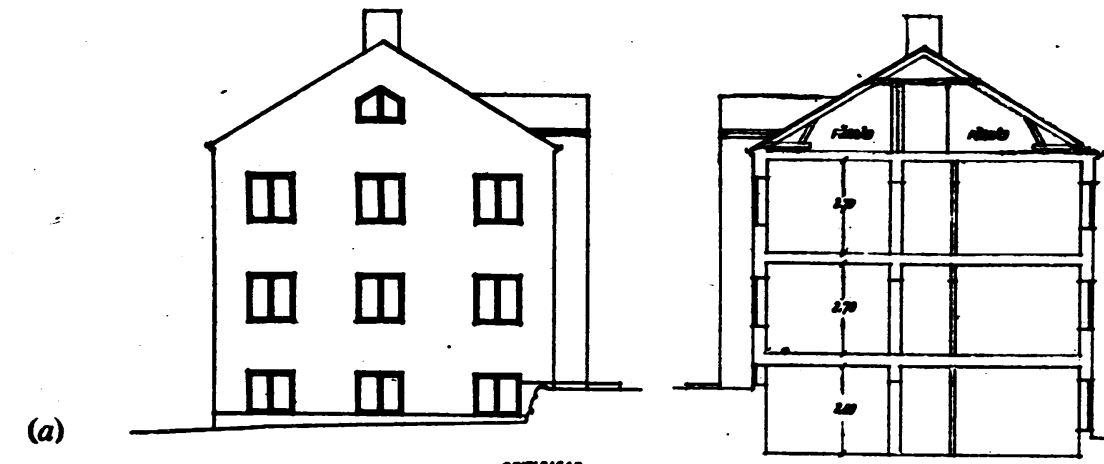

FIG. 15.-Drawings for a hostel for con- $\frac{\overline{3}}{3}$ valescent patients $\square$ from the official re-ce? port of the Social $\rightrightarrows$ Department, $1944: \stackrel{5}{?}$ $(a)$ and $(c)$ show sideo façade and frontage, 으 (b) a section through $\bar{p}$ the buildings, and $\bar{D}$ (d) and (e) the ground floor andw basement plans re- $\overrightarrow{0}$ spectively.

(b)

re- $\overrightarrow{0}$

(c)
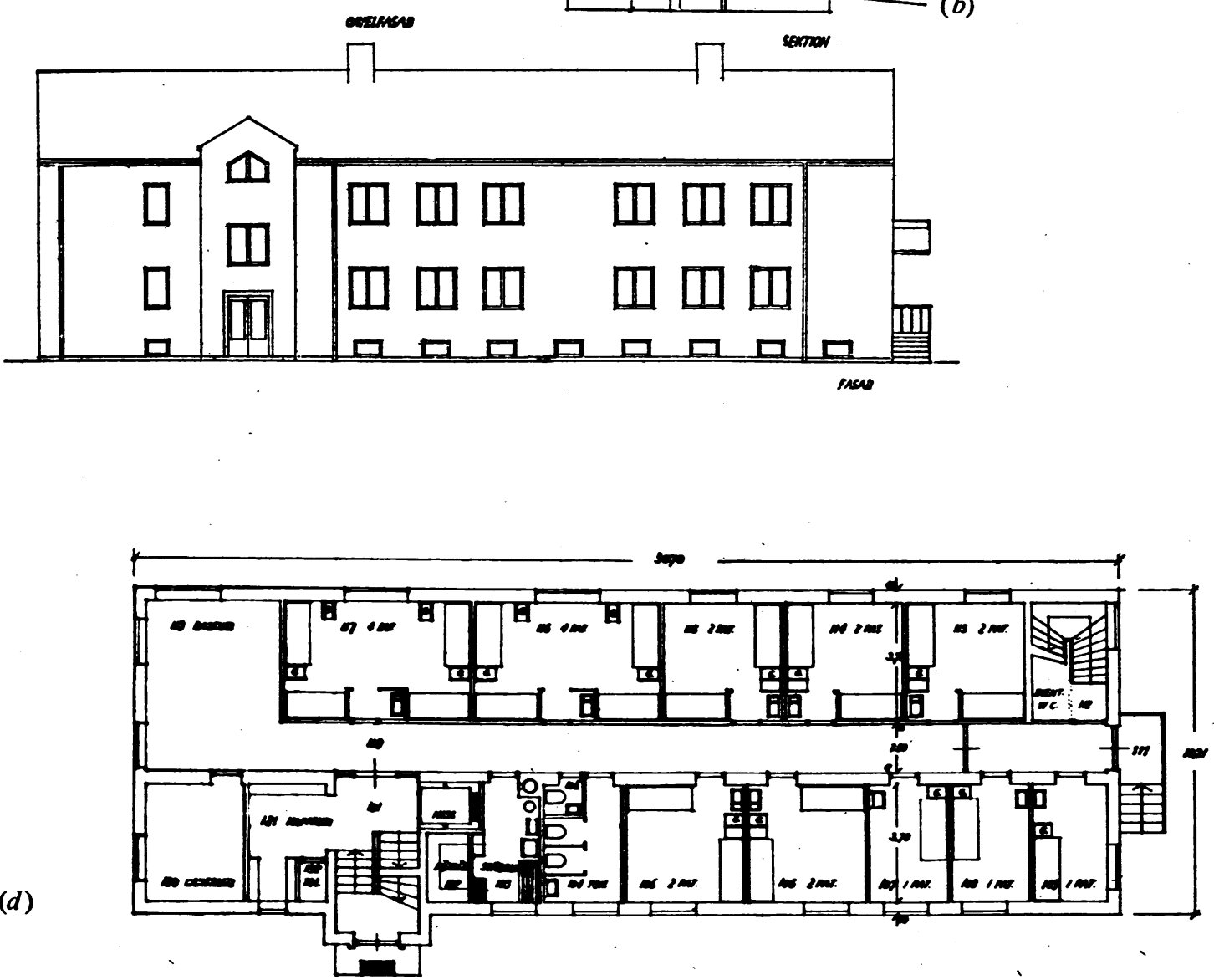

(e)

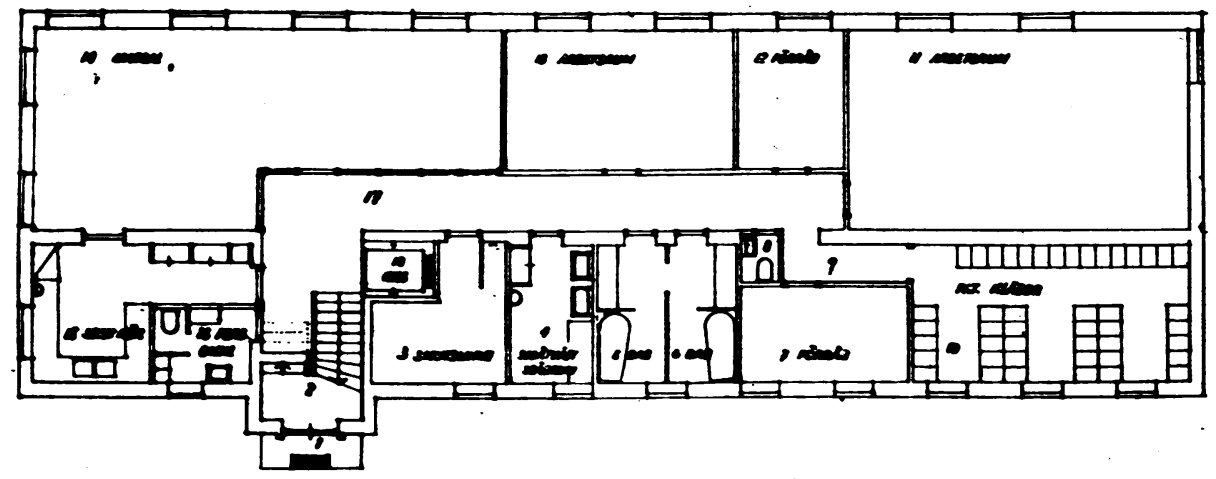

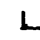<smiles>[Li][13CH3]</smiles>

$1+1+1$

re 
to be special rheumatism wards, I think we should also have orthopaedic wards linked with them. But we cannot build as many hospitals as we should liké to do in these days, because we have not enough coal to make bricks, and because we must export a lot of our building materials to people who are in still greater need of houses and hospital beds than we are, especially to the formerly occupied countries.

Another question which is not yet finally agreed upon is after-care. Should there, in connexion with our first-class hospitals, be hostels where the patients who are on their feet could stay for some time and be controlled and treated in the outpatient department of the hospital? This arrangement is not as cheap as one would think, amounting to some $50 \%$ of the cost of building an A-hospital, and some $75 \%$ of the running cost. With others, I think that about $20 \%$ of beds in every hospital ought to be given over to patients needing after-care.

The Committee has worked out a special report about these hostels (Official Report of the Social Department, 1944: p. 28) with a number of drawings. One example is given in Fig. 15.

The present Parliament has promised to give more money for building wards for chronic sick at the central county hospitals. In ten years we believe we should have between 15,000 and 20,000 such beds for old age. We have now only a third of what are needed. In Sweden as in Europe generally, the older age-groups in the next fifty years are going to be over-represented in numbers. We are, therefore, preparing for chronic diseases of old age on a large scale. Rheumatic diseases are in the front rank of these. We expect to have more than 2,000 of our required 3,000 beds very soon: 550 in internal wards, 450 in special rheumatic wards, some 750 in hostels, and at least 500 in central wards for chronic sick. Half these beds are needed to provide hospital care for rheumatic patients who have no such care at all, the other half for giving the rheumatic patients a reasonable length of time in hospital. More detailed figures are given in the Report from the Social Department 1945: p. 41.

Some arrangement is made for the follow-up and out-patient care of the rheumatic sick in connexion with the out-patient department for internal diseases. But the organization is not as it should be. We have not yet enough social workers. A special committee recently proposed a fixed number of social workers for every hospital of a certain size, but the Minister has not yet put this before Parliament. We intend to organize a follow-up in connexion with the special wards as soon as they are functioning with their special chiefs. We do not think that a comprehensive dispensary organization distinct from the work of the general family doctor is appropriate. But a specialist control service, attached to the out-patient department of the special wards and working in close connexion with the family doctor and his nurses in the districts, we think will be useful. This will be one detail in a comprehensive scheme for a complete and effective health service such as we are trying to build up, just as you are in Britain. Every year Parliament organizes fifty new rural districts for physicians; and nursing district vacancies are little by little filled as the nurses leave the training school for district nurses. District nurses and district family doctors will attend rheumatic patients in their homes.

In Sweden we have had a socialized hospital service working well since 1870 , a district physician service for 250 years, and a rural district nursing system for 20 years. We plan soon to have an organization of medical gymnasts spread over the country. But it will take 15 years fully and finally to realize these district plans, because we are so short of doctors, nurses, and gymnasts. We have, for example, one physician to 1,600 inhabitants, where you have one to 1,100 .

In Lund the academic wards for rheumatic patients are to be doubled. In Stockholm the last Parliament fixed the site and gave money for a new rheumatic hospital as a part of the Caroline Hospital, side by side with the new Research Institute. In Uppsala we also proposed and had plans drawn up for a central rheumatic and orthopaedic institution of 150 beds, but this has been postponed by a vote of the academy itself. In the old University of Uppsala there are many old buildings that really need to be replaced, and the question of priority is, therefore, acute. So they once more are reviewing their plans for the Medical City of Uppsala. Our Swedish love of planning sometimes endangers action!

\section{Concluding Remarks}

There seems to be a curious lack of system in our building of rheumatic wards. Generally, you in Britain begin by establishing university wards under a professor, who works, teaches his staff, and prepares young doctors to take over responsibilities at the periphery. We, on the contrary, began with beds in special isolated institutions and later in county hospitals, and are finishing by establishing university hospitals. It would be possible to philosophize about this order, but $I$ do not think it necessary. The whole organization of the care of rheumatic patients is being completed because the rheumatic diseases themselves necessitate it. All in all, it may be said that for a long time there has been a certain activity on the rheumatological front, and that at the moment in Sweden this activity is considerable. Some months ago Edström and others founded the Swedish General Association for fighting rheumatism. This Association is connected with $\stackrel{\oplus}{?}$ other great national movements, such as the Labour 7 Movement, the Association of Employers, the $\bar{D}$ Health Insurance Movement, the Swedish Medical Association, the Nurses' Association, and the $\stackrel{\mathbb{D}}{\varrho}$ Association of Social Workers. The nearest model 음 for our body is the Danish association, but our prototype is the Empire Rheumatism Council. We are beginning with the education of the medical profession and the public. Then, I think, an 
experimental colony for tropical rheumatic treatment may be established somewhere in Africa.

I do not know whether even acute rheumatic arthritis is a single aetiological unity. The chain of interfering factors may be rather complex. While we are now proceeding in Sweden to tackle these difficult problems in our own corner of the globe, we look to English science, with its obstinate perseverance on sound scientific lines, for the flash of inspiration. We know that the rheumatic diseases are, if not a monopoly of the British Isles, at least for some reason very favoured in them. From the depth of the fog we hope for the word from British science: let there be light!

(For further Illustrations of this Article see page 197) 